\title{
Verbum
}

Volume 6 | Issue 1

Article 11

December 2008

\section{Social Psychology of Religion}

Jessica M. Gifford

St. John Fisher University

Follow this and additional works at: https://fisherpub.sjf.edu/verbum

C. Part of the Religion Commons

How has open access to Fisher Digital Publications benefited you?

\section{Recommended Citation}

Gifford, Jessica M. (2008) "Social Psychology of Religion," Verbum: Vol. 6: Iss. 1, Article 11.

Available at: https://fisherpub.sjf.edu/verbum/vol6/iss1/11

This document is posted at https://fisherpub.sjf.edu/verbum/vol6/iss $1 / 11$ and is brought to you for free and open access by Fisher Digital Publications at. For more information, please contact fisherpub@sjf.edu. 


\title{
Social Psychology of Religion
}

\begin{abstract}
In lieu of an abstract, below is the essay's first paragraph.

"John Polkinghorne's description of God offers an insight into what supports his belief in God. Each religion has a specific description of who God is understood to be. Polkinghorne believes that God must have a purpose, and a mind with which to ponder this purpose and make decisions. While we may not be clear on what this purpose is and to what extent this mind reaches, Polkinghorne believes that the universe would not otherwise exist without the presence of God. He does not explain why God's presence is veiled, but there has never been a case of anyone claiming to be the almighty creator and proving it. Many religions teach that God is always with us, (in our hearts, in our minds, in the flowers, etcetera,) and that we must have faith even though we cannot see or hear him. Because of this "veiled presence," he is worthy of worship. The idea of God fosters hope among believers. Those who believe are comforted in knowing that this hidden being has a plan for everyone, and while we might not know what that plan is, we have faith that God will us pull through somehow."
\end{abstract}




\section{Social Psychology of Religion}

\section{Jessica. M. Gifford}

John Polkinghorne's description of God offers an insight into what supports his belief in God. Each religion has a specific description of who God is understood to be. Polkinghorne believes that God must have a purpose, and a mind with which to ponder this purpose and make decisions. While we may not be clear on what this purpose is and to what extent this mind reaches, Polkinghorne believes that the universe would not otherwise exist without the presence of God. He does not explain why God's presence is veiled, but there has never been a case of anyone claiming to be the almighty creator and proving it. Many religions teach that God is always with us, (in our hearts, in our minds, in the flowers, etcetera,) and that we must have faith even though we cannot see or hear him. Because of this "veiled presence," he is worthy of worship. The idea of God fosters hope among believers. Those who believe are comforted in knowing that this hidden being has a plan for everyone, and while we might not know what that plan is, we have faith that God will us pull through somehow.

In chapter two, of "The Sacred Depths of Nature," Goodenough addresses the issue of belief in God based on the idea that all the circumstances were too perfect for life to develop that it must have been set into motion by God. She suggests that perhaps we recognize what a miracle it is that the circumstances happened by chance and celebrate other miracles of science. It is not the "higher power," but emergence and evolution that allow us to entertain the possibility of a higher power. I think that her point is one of the most important ideas for anyone, religious or not, to consider. We obsess over the 
existential condition and metaphysical questions so often that we often loose sight of the beauty and wonder around us right here, right now. Let us stand humble in awe of the sunset, of a new life being born, or of an incredible story about a dog rescuing a child. Perhaps what we should worship is simply the miracle of our existence, rather than an idea, which we cannot prove because we cannot see or hear it.

Many believe that a belief in God and engagement in a religious faith tradition are linked with personal salvation. Christianity teaches that the road to salvation involves living as Jesus would and repenting when one sins. God will forgive sinners if they acknowledge their error, apologize for it, and ask for forgiveness from God. Many religions also believe that anyone outside the faith tradition who does not convert will suffer eternity in the depths of hell when their messiah returns. For me, this idea that one's destiny is at the hands of some God whom I have never met, seems like a pretty big leap of faith. It also removes a large amount of accountability from the people. If people can commit all kinds of criminal and moral wrongs then simply repent to buy their way back into heaven, what is the point of investing anything more than an hour each week during which to apologize for sins? Some people I have spoken with who are not practitioners of a specific faith tradition are not worried that they are missing their own personal salvation. Still others believe that the road to salvation is directly linked with the path we follow on a daily basis. If we practice positive thinking, treat others respectfully, and lead our lives in a generally positive manner, then we bring about our own salvation based on karma. However, karma is occasionally also a tough pill to swallow when we examine horrors of the world such as poverty or abused children. Where do these kinds of suffering fit into the karmic circle? How can one claim that an 
abused child "brought it on himself?" I think that for those who believe in any kind of personal salvation, faith and God play at least a minor if not major role. The idea of salvation brings us comfort we do not believe we can find by ourselves. A "hope for better things to come" is the foundation upon which many religious beliefs are based.

I am a firm believer in karma and reincarnation. However, I do not have a view on whether the karma in this life affects your reincarnation in the next life, (suppose you are a murderer in this life in the next life you might be reincarnated as a murder victim.) I believe that my path to personal salvation is how I live my life here and now. Through living peaceful, truthful, and temperate life now, I manifest a peaceful, truthful, and temperate life full of love for the rest of my future here in this body.

If I were to become absolutely convinced that there is a God, I do not believe that my relationship to material objects and people would change drastically or immediately. I would wish to know what God's expectations of me were and how I should go about meeting those expectations. I think that if God were to convince me that he or she was real, my relationship to material possessions and other people would change based on what this God told me to do. If God asked me to pray, give up candy, or sing a song, I would likely do so assuming these requests had some sort of reasoning behind them. I think that if God were to ask his people to behave in a certain way, he would be expected to explain his reasoning in some respect. However, I would have a very hard time if this God were to dictate evil advocating ideas such as murder or suffering. As a generally peaceful and loving person, I would find it hard to believe that "God were evil." If anything is possible, (even if it is not probable,) it is conceivable that God might not be so nice after all. 
As I am already a member of believers in evolution, my actions and thoughts would not change if evolution were to be proven as fact. While I entertain the possibility that there is some omnipotent being who may or may not have a hand in our lives and the existence of the universe, I also find the scientific evidence for evolution believable and rock solid. Both can exist, (at least in my mind,) because one does not necessarily contradict the other. If there was a "big bang," there must have been something before. I find it conceivable that God caused the big bang and then sat back to watch the show. While it seems a bit odd for God not to interfere, it is possible. Jerry Coyne makes a good point in his discussion of the argument to include creationism in high school science classes; "It makes as little sense to doubt the factuality of evolution as to doubt the factuality of gravity," (Coyne 5.) While I have deep regard for the possibility of anything, the overwhelming evidence for evolution is, well, overwhelming. The fact that the idea is falsifiable, makes is a sound scientific theory. As Coyne points out, the term "theory" does not imply guess, it is supported with vast amounts of reliable evidence.

If my beliefs in reincarnation were shattered by proof that dead is dead, I would be okay with that. While I find the idea of reincarnation comforting, my spirits would not be crushed if I were to learn I was mistaken. I think that I might take the death of my close friends and family much harder than I do now. When I am occasionally saddened over missing my greatest friend who was also my grandmother, I find I am comforted by the idea that her spirit is always with me, smiling down on me, and that I may one day have the chance to interact again with her spirit. I think that for many people, the idea of a lingering spirit or the possibility of reuniting helps ease the pain of loss. I might also strive harder to live my life in a positive manner so that I may leave a legacy of love, 
peace, and tolerance to those who will remember me when I am gone. Reincarnation offers the chance to fix in the next life what one might have screwed up in this one. If there is no chance of making up for wrongs done or lost time, I think I would be compelled to make more sacrifices in an effort to ease suffering and promote harmony among the people who I interact with.

If I were to discover that the veiled presence did in fact exist but did not care and paid no attention to our plight as humanity, I would initially feel somewhat disillusioned. However, I do not believe that my actions would change given that I do not believe in a single, Christian God now. As I said before, I am willing to entertain the possibility that God is not loving, kind, or caring, however, I would indeed be disappointed if I were to learn that God did exist but did not care. If God did exist but left the universe on autopilot, I would not wrestle with the issue for long. I compare this idea of an uncaring God to the omnipotent "Q" of the Star Trek series who shows up in both "ST: The Next Generation," and "ST: Voyager." Q is an all powerful, omnipotent, non-corporeal being who takes human form in order to interact with the captains and crew of the Enterprise and Voyager. Q can do literally anything with the "snap of his fingers" or "twitch of his nose," including travel to the end of the universe, manifest starships into existence from thin air, and even set up a scenario in which Captain Picard has the chance to change his past and future on more than one occasion. If some being such as Q existed and claimed to be God, there is no way we could deny this claim. It is possible that the omnipotent creator we have named God has become bored with his simple and feeble creation in comparison to the expanse of the universe. Who are we to think we are so special that we deserve God's attention and help? If he created us, he likely created others on other 
planets in other galaxies far away. Perhaps another people have captured his attention in a way that he deems more important. Maybe these other people have found a way to move beyond their personal greed, have become enlightened, and have eradicated war and disease by evolving into a peaceful race.

The belief in God, salvation, and reincarnation ease the pain of life as we know it because it offers a reason to become more than we are. These ideas offer humanity something for which to work. Our suffering might pay off if there is a God who will reward us at the end. In many ways, this can help us feel as though our lives are worth living. Humans look for ways to affirm that their lives have meaning and our actions are meaningful. The existence of God offers someone for us to look up to, to strive to be, one to look for answers from, one to ask forgiveness of. We are often our own harshest critics. If there is a God, he might offer us guidance in order to change our ways. God's existence excuses us from the harsh task of judging ourselves. Reincarnation and salvation offer us a possibility for something greater still to come after death, and so the pain of death is easier to cope with. While many wars have been fought in the name of God, ultimately I believe that religion's colorful and sometimes not so agreeable past is for the greater good of those who truly follow the practices of the religious doctrines. Extremists claiming to be Islamic fundamentalists acting in the name of Mohammed are not in fact practicing the ways of Islam, which they claim is the basis for the horrific acts they commit. Catholic priests who molest children are not representative of the Bible's teachings and messages. Sometimes the few bad sheep give a bad name to the whole flock. Religion, when used in a positive manner, offers many things to groups of people with common beliefs ranging from emotional and financial support, to mental health 
services, a sense of community and belonging, and even new friends and romantic partnerships. The teachings of Jesus do not need a religious context in order for one to understand them. One needs only read the teachings of Jesus from a human perspective. As humans, we are all connected whether we like it or not. Religion can divide, but its greatest benefit is that it can also unite. 